\title{
Mineral Turpentine Adulterant in Lubricating Oil
}

\author{
RAGHUNATH TOCHE ${ }^{1}$, SHOBHA BORADE ${ }^{2}$, \\ MADHUKAR MALVE ${ }^{3}$ and BHAUSAHEB MORE ${ }^{3^{*}}$ \\ ${ }^{1}$ Deparrtment of Chemistry, KTHM College, Nashik, India \\ ${ }^{2}$ S M B S T College, Sangamner, Ahmed Nagar, India \\ ${ }^{3}$ Directorate of Forensic Science Laboratories, Kalina, Santacruz, Mumbai-400098, India \\ bhaumore1@gmail.com
}

Received 11 July 2015 / Accepted 24 July 2015

\begin{abstract}
Mineral turpentine oil (MTO) is used to adulterate lubricating oil. The kinematic viscosity and flash point of lubricating oil and mineral turpentine oil samples are nearly $1.2 \mathrm{~mm}^{2} / \mathrm{s}$ and $360{ }^{\circ} \mathrm{C}$ respectively. But adulterated samples of lubricating oil showed proportionate decrease in kinematic viscosity and flash point with percentage of mineral turpentine oil. This fact was used to detect adulteration of lubricating oil. The gas chromatographic analysis of the distillate of suspected lubricating oil sample when compared with standard mineral turpentine oil also showed the presence of mineral turpentine oil as adulterant. This approach was used to detect adulterated lubricating oil samples referred to forensic laboratories.
\end{abstract}

Keywords: Forensic sciences, Lubricating oil, Kinematic viscosity, Flash point

\section{Introduction}

In several countries, fuel adulteration is very common, this is because the products of comparable quantities have different price. Now a days fuel dealers do adulteration so as to make maximum profit. Adulterated fuel may damages motor vehicles and other harmful gas effect to human health ${ }^{1}$. Adulteration is a criminal act, therefore the government authorities like Police and food and civil supply departments monitor the quality of petrol and diesel from dealers by random collection of samples and screening it for adulteration in forensic and other authorized laboratories.

Lubricating oil is consist of mixture of $\mathrm{C}_{28}$ to $\mathrm{C}_{40}$ hydrocarbons blended with 2 to $20 \%$ additives mainly paraffin, naphthalene, aromatics and the base stock obtained during petroleum refining by-products. The lubricating properties of oil mainly depend up on their viscosity and the length of hydrocarbon chain. The most important properties of lubricating oil are density, flash point, kinematic viscosity. The viscosity index is governed by BIS specifications IS 496:1982 2 . 
The function of lubricating oil is to reduce the friction between the two moving metallic or plastic surfaces with respect to each other. The performance efficiency and operational durability of internal combustion of engine depends on quality of lubricating oils ${ }^{3}$.

The lubricating oils are available in market in different trade names based on their purity and use in engine. They are more expensive than petrol, diesel, kerosene and mineral turpentine oil. Also they are susceptible for adulteration and hence the illegal syndicates for monitory gain adulterate it with turpentine oil. In Nashik region mineral turpentine oil is cheaply available and mainly used as an industrial solvent, for organic synthesis, thinner for oil paints and in adhesives ${ }^{4-6}$. Different workers reported various instrumental techniques for detection of adulterants in lubricating oil $^{7-12}$.

In our previous work, we described analysis of adulteration of diesel by measuring kinematic viscosity ${ }^{13}$. In this paper, we study the physical properties such as kinematic viscosity, flash point and gas chromatography analysis for determination adulteration in lubricating oil.

\section{Experimental}

Mineral turpentine oil and lubricating oil samples were procured from refineries. Admixtures of lubricating oil in mineral turpentine oil in the ratio (9:1), (8:2), (7:3), (6:4), (5:5), (4:6), (3:7), (2:8) and (1:9) were prepared. Gas liquid chromatography (Model-5765- Nucon Gas Chromatograph, India) coupled with Flame ionization detector. Viscosity was measured using Anton Paar (Stabinger) Viscometer (SVM3000/G2) by using toluene solvent at $40{ }^{\circ} \mathrm{C}$ temperature. The operating parameters were used are shown in Table 1.

Table 1. Instrument parameters

\begin{tabular}{cc}
\hline Instrument & Operating parameters \\
\hline Column (packed) & Apizeon-L10\% \\
Carrier gas & Nitrogen $30 \mathrm{~mL} / \mathrm{Min}$ \\
Fuel & Hydrogen $35 \mathrm{~mL} / \mathrm{Min}$ \\
Air & $350 \mathrm{~mL} / \mathrm{Min}$ \\
Oven initial temp & $120{ }^{\circ} \mathrm{C}$ \\
Heating Rate & $10{ }^{\circ} \mathrm{C}$ \\
Oven final temp & $220^{\circ} \mathrm{C}$ \\
Injector temp & $220^{\circ} \mathrm{C}$ \\
Detector temp & $250{ }^{\circ} \mathrm{C}$ \\
\hline
\end{tabular}

Ten different samples of mineral turpentine oil and lubricating oil were obtained from different standard sources. $2 \mathrm{~mL}$ of sample was injected to sample cell and the kinematic viscosity was measured twice at $40{ }^{\circ} \mathrm{C}$. If relative standard deviation is below $2 \%$, the instrument shows valid results and gives the actual value of kinematic viscosity (Table 2). The flash point of standard lubricating oil and mineral turpentine oil was measured on (Pensky Martens ASTM D 93) instrument B. Flash point of ten different samples of mineral turpentine oils were taken on A (ABEL IP 170, Table 3). The admixtures of lubricating oil in mineral turpentine oil in the ratio (9:1), (8:2), (7:3), (6:4), (5:5), (4:6) (3:7), (2:8) and (1:9) were prepared and their kinetic viscosity and flash points were recorded as discuss above shown in Table 4. 
Table 2. Kinematic viscosity and flash point of ten different lubricating oil samples

\begin{tabular}{ccc}
\hline Sample No. & $\begin{array}{c}\text { Kinematic viscosity } \\
\text { at } 40{ }^{\circ} \mathrm{C} \text { in } \mathrm{mm}^{2} / \mathrm{s}\end{array}$ & $\begin{array}{c}\text { Flash point } \\
{ }^{\circ} \mathrm{C}\end{array}$ \\
\hline 1 & 356 & 191 \\
2 & 362 & 192 \\
3 & 358 & 190 \\
4 & 359 & 193 \\
5 & 361 & 194 \\
6 & 361 & 195 \\
7 & 360 & 192 \\
8 & 356 & 194 \\
9 & 356 & 193 \\
10 & 363 & 193 \\
Average & 359.2 & 192.7 \\
\hline
\end{tabular}

Table 3. Kinematic viscosity and flash point of ten different mineral turpentine oil

\begin{tabular}{ccc}
\hline Sample No. & $\begin{array}{c}\text { Kinematic viscosity } \\
\text { at } 40^{\circ} \mathrm{C} \text { in } \mathrm{mm}^{2} / \mathrm{s}\end{array}$ & $\begin{array}{c}\text { Flash point } \\
{ }^{\circ} \mathrm{C}\end{array}$ \\
\hline 1 & 1.2036 & 30 \\
2 & 1.2532 & 32 \\
3 & 1.2456 & 35 \\
4 & 1.1986 & 33 \\
5 & 1.2218 & 32 \\
6 & 1.2613 & 34 \\
7 & 1.2017 & 31 \\
8 & 1.2741 & 33 \\
9 & 1.2215 & 35 \\
10 & 1.2340 & 32 \\
Average & 1.23154 & 32.7 \\
\hline
\end{tabular}

Table 4. Kinematic viscosity and flash point of ten different mineral turpentine oil and lubricating oil mixtures

\begin{tabular}{cccc}
\hline MTO & Lubricating oil & $\begin{array}{c}\text { Kinematic viscosity } \\
\text { at } 40{ }^{\circ} \mathrm{C} \text { in } \mathrm{mm}^{2} / \mathrm{s}\end{array}$ & $\begin{array}{c}\text { Flash point } \\
{ }^{\circ} \mathrm{C}\end{array}$ \\
\hline 10 & 0 & 363 & 194 \\
9 & 1 & 109 & 69 \\
8 & 2 & 50 & 56 \\
7 & 3 & 22 & 52 \\
6 & 4 & 14 & 50 \\
5 & 5 & 7 & 48 \\
4 & 6 & 6 & 46 \\
3 & 7 & 5 & 45 \\
2 & 8 & 3 & 44 \\
1 & 9 & 2 & 43 \\
0 & 10 & 1 & 42 \\
\hline
\end{tabular}


The kinetic viscosity and flash points of suspected adulterated samples (unknown samples) were also measured by same procedure. Suspected adulterated samples were distilled and the collected distillate sample $(0.5 \mathrm{uL})$ was injected at identical condition of Apeizon-L column (LabSpere Inc) and chromatogram was recorded. Similarly, control sample $0.5 \mathrm{uL}$ of mineral turpentine oil was injected at same condition and chromatograms was recorded. The chromatogram obtained was compared with standard mineral turpentine oil samples as shown in Figure 1 and 2.

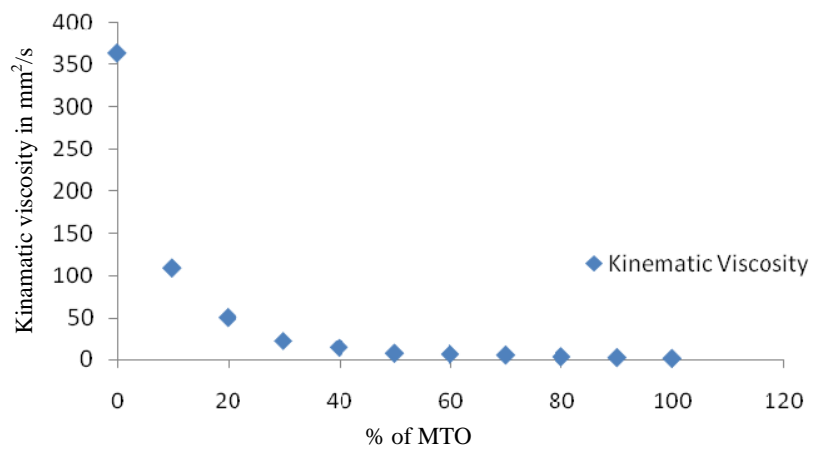

Figure 1. Graph of kinematic viscosity vs. percentage of MTO

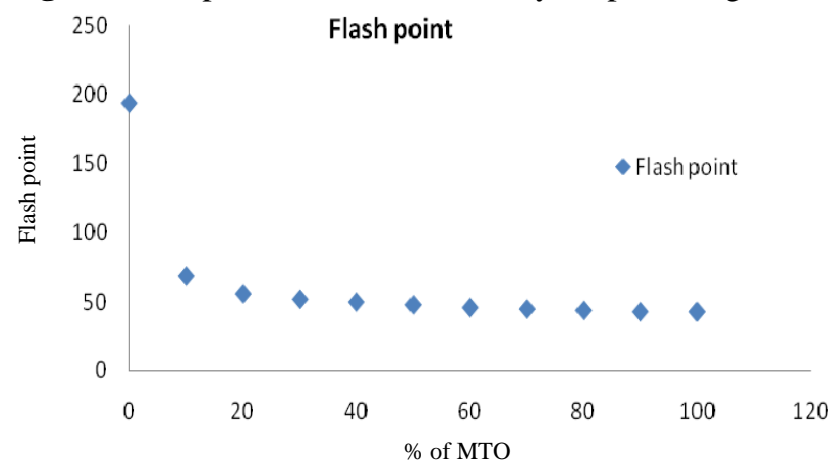

Figure 2. Graph of flash point vs. percentage of MTO

\section{Results and Discussion}

When liquid flows through tube the liquid layer in contact with wall of the tube is stationary where as the liquid in the center has high velocity. Intermediate layers move with a gradation of velocities. The flowing liquid may therefore be regarded as composed of a number of concentric tubes sliding over other. Each layer exerts a drag on the next and maintains the flow. This internal friction produces retarding force to oppose the flow of liquid. The kinematic viscosity depends on molecular size (length in particular) and on the magnitude of intermolecular force.

The values of kinematic viscosity in $\mathrm{mm}^{2} / \mathrm{s}$ of ten different lubricating oil samples ranges from 355 to $365 \mathrm{~mm}^{2} / \mathrm{s}$ (average 359.5) and flash point ranges from 193-190 ${ }^{\circ} \mathrm{C}$ (average 359.5) shown in Table 2. The kinematic viscosity of ten different MTO samples ranges from $1.2036-1.2741 \mathrm{~mm}^{2} / \mathrm{s}$ (average 1.2315, Table 2) and flash point ranges from $30-34{ }^{\circ} \mathrm{C}$ (average 32.7 , Table 3 ). The kinematic viscosity of admixtures decreases sharply up to $70 \%$ with increase in percentage of MTO in lubricating oil (Table 4). 
The hydrocarbons in lubricating oil $\left(\mathrm{C}_{28}\right.$ to $\left.\mathrm{C}_{40}\right)$ have flash point about $192{ }^{\circ} \mathrm{C}$ and kinematic viscosity is about $360 \mathrm{~mm}^{2} / \mathrm{s}$. The measurement of flash point and kinematic viscosity of ten different samples of lubricating oil and ten different samples of MTO (Table 2 and 3), indicated that when lubricating oil is adulterated with $10 \%$ mineral turpentine oil, the flash point sharply decreases to $69{ }^{\circ} \mathrm{C}$ and kinematic viscosity sharply decrease to $109 \mathrm{~mm}^{2} / \mathrm{s}$ as shown in Figure 1 and 2. Due to high price of lubricating oil the illegal syndicates adulterate lubricating oil with MTO. The diesel engine performance is a function of compression ratio, injection time and ignition temperature. These parameters are depending on the quality of lubricating oil. Advance analytical instruments like gas chromatography, mass spectroscopy, kinematic viscosity and flash point can be used for detection and measurement of adulteration in lubricating oil.

The suspected adulterated samples were analysed by same method and results are shown in Table 5. The flash point and viscosity analysis indicated that the suspected sample is adulterated. The type of adulterant can be found out by gas chromatographic analysis by comparing the chromatogram of distillate with standard MTO (Figure $3 \& 4$ ). The two chromatograms are identical indicated that the lubricating oil is adulterated with MTO.

Table 5. Kinematic viscosity and flash point of unknown suspected lubricating oil samples

\begin{tabular}{ccc}
\hline Sample & $\begin{array}{c}\text { Kinematic viscosity at } 40{ }^{\circ} \mathrm{C} \\
\text { in } \mathrm{mm}^{2} / \mathrm{s}\end{array}$ & Flash point in ${ }^{\circ} \mathrm{C}$ \\
\hline 1 & 110 & 71 \\
2 & 98 & 68 \\
3 & 122 & 73 \\
\hline
\end{tabular}

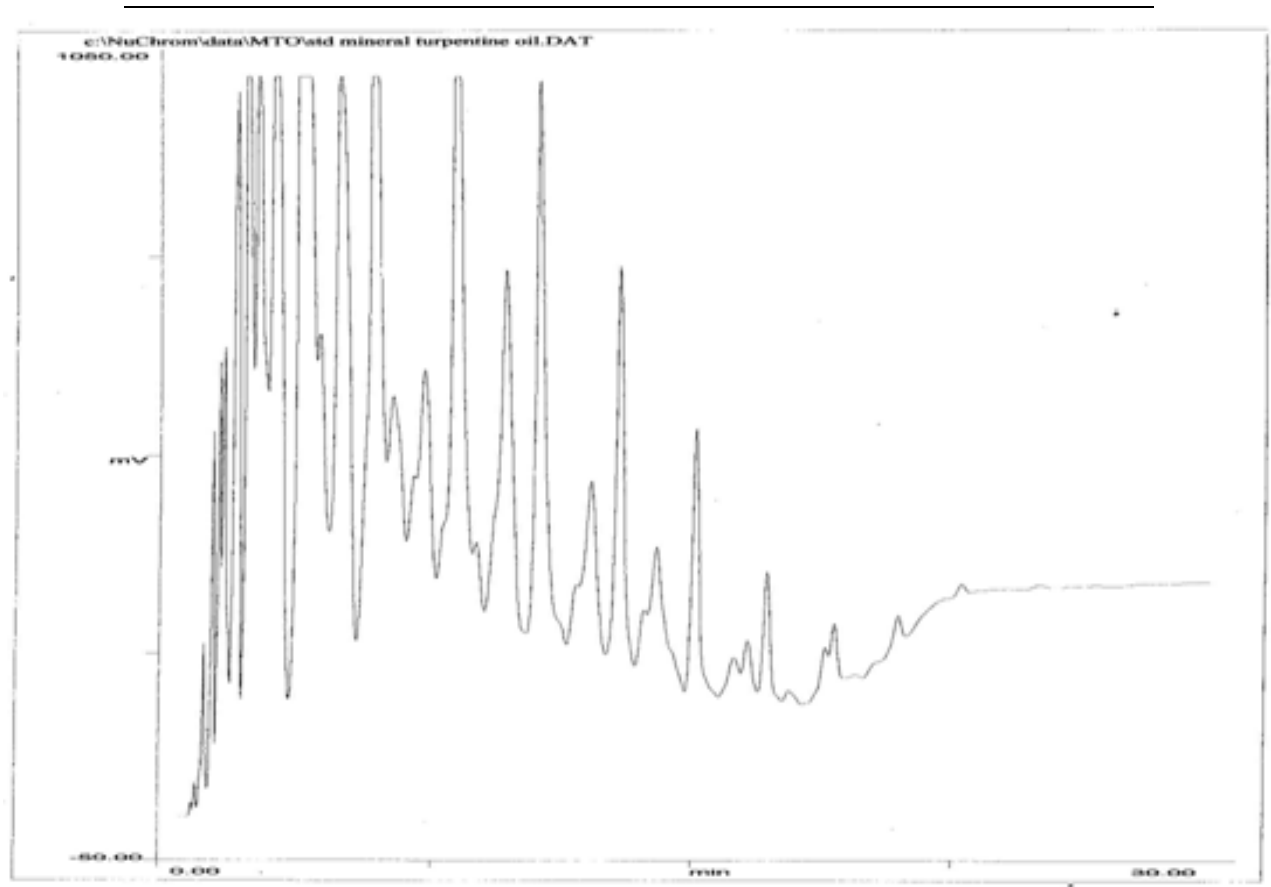

Figure 3. GC chromatogram of MTO 


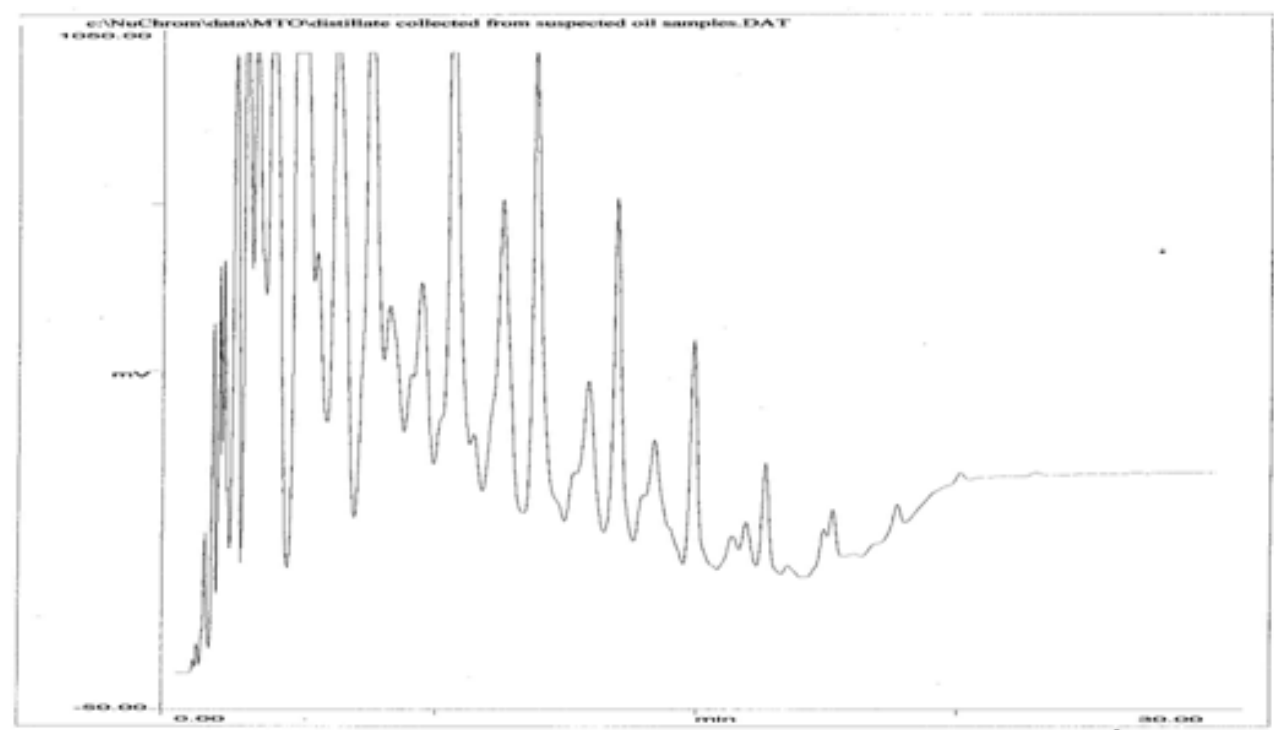

Figure 4. GC chromatogram of distillate collected from suspected adulterated lubricating oil

\section{Conclusion}

Measurements of kinetic viscosity, flash point are simple techniques for the determination of adulteration in lubrication oil and gas chromatography is important analytical tool can be used to find the type and percentage of adulterant.

\section{References}

1. Osueke C O and Ofondu I O, International Journal of Mechanical \& Mechatronics Engineering, 2011, 11(4), 32-35.

2. $\quad$ Specification for Lubricating Oil, BIS Specifications IS, 1982, 496.

3. Manual on Petroleum Products and their Forensic Analysis, by Indian Institute of Petroleum, Dehradun, 2001, 21, 66.

4. Specification for MTO IS: 1978, 1745.

5. Malve M K and Srivastava A K, Ind J Criminol Criminal., 2005, XXVI(3), 54-61.

6. Malve M K and Srivastava A K, Ind J Criminol Criminal., 2006, XXVII(1), 83-94.

7. Standard Methods for analysis and testing of petroleum and related products and British Standards 2000 parts, Institute of Petroleum, London, method IP 123/93, 2002.

8. Malve M K and Srivastava A K, Ind J Criminol Criminal., 2004, XXV, 105-114.

9. Palus B, Cielniak J Z, Forensic Sci Inter., 2000, 112(2-3), 81-90; DOI:10.1016/S0379-0738(00)00172-9

10. Varotsis N and Paeadikis N, Ind Engg Chem Res., 1997, 36(12), 5516-5519; DOI:10.1021/ie970463m

11. Rao C R, Reddy L C S and Porabhu C A R, Current Sci., 1980, 49(5), 185-186.

12. Lovell W G, Campell J M and Boyd T A, Ind Eng Chem., 1931, 23, 26-29.

13. More B P, Malve M K, Toche R B and Shinde D B, Inter J Pharm Bio Sci., 2012, 2, 256-261. 